\title{
Troop Takeover and Reproductive Success of Wild Male Japanese Macaques on Yakushima Island (Macaca fuscata yakui)
}

\author{
Sachiko Hayakawa ${ }^{1}$ and Joseph Soltis ${ }^{2}$ \\ ${ }^{1}$ Department of Cognition, Primate Research Institute, Kyoto University, Kanrin Inuyama-shi, Aichiken 484-8506, Japan \\ ${ }^{2}$ Education and Science, Disney's Animal Kingdom, 1200 North Savannah Circle East, Lake Buena Vista, FL 32830, USA \\ Correspondence should be addressed to Sachiko Hayakawa, shayakaw@pri.kyoto-u.ac.jp
}

Received 1 January 2011; Revised 4 August 2011; Accepted 19 August 2011

Academic Editor: Luis Ebensperger

Copyright (C) 2011 S. Hayakawa and J. Soltis. This is an open access article distributed under the Creative Commons Attribution License, which permits unrestricted use, distribution, and reproduction in any medium, provided the original work is properly cited.

\begin{abstract}
Troop takeover is common in one-male primate groups, but there are few reports in multimale groups. Japanese macaques (Macaca fuscata) form multimale groups and males commonly join troops at the bottom rank. On Yakushima island, however, where group size is relatively small, entrance into groups at the alpha position is also observed. This paper reports on the general features of troop takeover, on the predictors of takeover events, and on the reproductive success of takeover males. Troop takeovers occurred only in the mating season; nontroop males (NTMs) did not cooperate with each other; former alpha males were rarely expelled from the troop; new alpha males did not commit infanticide; new alpha male tenure in the group was usually less than two years. Logistic regression analysis showed that the number of NTMs associating with a troop predicted the occurrence of troop takeover. Paternity discrimination revealed that $33.3 \%$ (3/9) of takeover males succeeded in siring offspring. Contrary to this low success rate, binary logistic regression analysis revealed that the takeover males can expect higher reproductive success compared to troop males. Entering a troop and out-competing the alpha male is one of many available strategies to attain reproductive success in male Japanese macaques.
\end{abstract}

\section{Introduction}

Male macaques migrate from their natal groups as they mature, often migrating among nonnatal groups several times during their lives. This behavior may increase the probability of attaining high rank and mating opportunities [1-4]. Group takeover is usually observed in one-male groups, but also sometimes in multimale groups (Japanese macaques: [5, 6]; long-tailed macaques: [3]; capuchin monkeys: [2]; Hanuman langurs: [7]). Male migration, including troop takeover, is usually concentrated in the mating season, although in long-tailed macaques migration can occur in any period [3]. It is often reported that new males kill infants during or after troop takeover $[8,9]$, increasing the probability of future matings. Resident males, including former alpha males, often defend infants from intruder males, especially when they are likely to be their offspring $[10,11]$.

In Japanese macaques, intertroop movement is observed in the mating season. It is common for males to enter troops peacefully (i.e., without aggression), assuming low status in the existing dominance hierarchy [12-16]. However, in Yakushima, many males visit adjacent troops as nontroop male, (NTMs) during the mating season, and mature NTMs at the peak of physical strength enter troops aggressively. The number of NTMs varies depending on the troop and year, and sometimes NTMs contribute up to $30 \%-40 \%$ of a troop's total copulations [5, 14]. Troop takeovers usually involve such mature intruder males and troops with small numbers of resident males, whereas young males tend to move into troops with many resident males [17]. Current alpha males and other troop males often attempt to expel intruders from the troop, which can result in serious injury to both parties [5]. Thus, entering as a dominant male poses some risk, so it is expected that the takeover strategy also provides some benefit, such as increased reproductive success.

In this study, our first objective is to describe the general feature of troop takeovers in this population. Previous studies on Japanese macaques showed that nontroop males 
(NTMs) usually enter troops after most of the troop females have already conceived, suggesting that males might fail to impregnate the females during the mating season $[18,19]$ but see [20]. If a male is unable to find receptive females in the troop, he may commit infanticide so that lactating females would begin cycling again. However, only one case of infanticide has been reported in this population [21]. Another important factor is the tenure of the alpha male. Usually, the male macaques shift between troops throughout their lives. If a male remains in a troop as an alpha male for many years after takeover, it might ensure high reproductive success. The average male tenure of the Yakushima population is believed to be around 2 to 3 years [5].

We also examine predictor variables that may influence the probability of troop takeover (number of troop males, number of troop estrous females, and number of NTMs), using logistic regression analysis. Finally, we examine the reproductive success of takeover males using noninvasive collection of DNA samples, and we compare the reproductive success of takeover males to that of low- and high-ranking resident males.

\section{Method}

2.1. Study Site and Subjects. The study site is located on the western coast of Yakushima Island $\left(30^{\circ} \mathrm{N}, 130^{\circ} \mathrm{E}\right)$, Japan. The investigation was conducted on 4 troops, referred to as troops B, NA, E, and Momoe. Habituation and long-term research on these troops began on 1992, 1994, 2003, and 2000, respectively [22-24] (Hayakawa; unpublished data). The troops inhabit a coastal broadleaf evergreen forest, which lies $0-350 \mathrm{~m}$ above sea level $[15,25]$. The population is characterized by many small troops with overlapping home ranges [26, 27]. Solitary floaters are rarely seen in the nonmating season, and the sex ratio of troop members is nearly $1: 1$ in this population, so most males are considered to belong to troops. And these NTMs are also believed to belong to certain troops. Many of these NTMs leave the troop within a few days and then are believed to enter another group or previous group by the end of mating season by losing a fight with troop males or for unknown reasons $[5,14$, 26].

This study covers a 6-year period for troop B, 5 years for troop NA, and 1 year for each troops E and Momoe, with some observation gaps in each data set. The study troops were monitored with respect to their membership size at least twice a year, during the mating season (Sep-Jan) and the nonmating season (Feb-Aug). During the mating season, observations are focused on the mating behavior of the members and on monitoring the NTMs. Behavioral sampling procedures varied over the period and troopsfor each distinct project. Troop B: Ad libitum sampling (1996) and focal animal sampling (1997 and 2003). In 1999 and 2000, behavioral data are not collected; however, female's estrous condition and her mating partner and visiting NTM were recorded; Troop NA: Focal animal sampling (1997 to 2000 and 2003); Troop E: Focal animal sampling (2003); Troop Momoe: Focal animal sampling (2003). For further details and the results of each project, see previous reports $[6,28]$.
Troop males are defined as males that have been observed in the troop from the previous nonmating season, and NTMs are defined as males that did not belong to the target troop in the previous nonmating season and first interacted with the troop after the onset of a mating season [20, 24]. Many NTMs are merely visitors who remain near the troop for only a few days to several weeks and then just disappear. Some NTMs dominate troop males and exhibit behavioral patterns that researchers term the "alpha-male attitude"; this attitude includes shaking trees while giving barking vocalizations and displaying aggressiveness toward the troop males [13]. Many of these males become the new alpha male of the troop, but some of them disappear before the end of the mating season $[5,6]$. In this study, these males who showed "alpha-male attitude" were also classified as NTMs.

In this research, we defined troop takeover as those cases in which males (1) visited the troop over a minimum of 20 days continuously or intermittently, (2) showed aggressive behaviors, such as branch shaking with vocalizations, staring at or chasing group males, and mounting group members in the center of the group, and (3) received submissive behaviors from the majority of troop males, including the alpha male.

2.2. DNA Isolation, Quantification, and Microsatellite Genotyping. Paternity data on this population has been reported previously $[20,21,28]$. Additional paternal discrimination was carried out for infants who were born in 2004 in the three troops which were taken over by NTMs. Samples were collected from the infants and their mothers, all the males of the troops under study, and 20 NTMs $(22.5 \%$ of all the observed NTMs) who interacted with troop females. DNA from adult males was extracted mainly from the semen of masturbating individuals or from semen that had dropped to the ground after copulation. DNA from mothers were mainly extracted from menstrual blood. DNA was extracted from the tissue sample of one infant who died two days after birth. The remaining individuals' DNA was extracted from multiple samples of urine, feces, and hairs (plucked by themselves or by groomers). Fresh samples were placed in $25 \mathrm{~mL}$ tubes containing absolute alcohol and stored at $4^{\circ} \mathrm{C}$ until extraction.

Genomic DNA was extracted using a QIAmp DNA stool kit and QIAmp DNA mini kit (Qiagen, Chatsworth, Calif) in accordance with the manufacturer's instructions. DNA from single shed hairs was extracted using an ISOHAIR kit (Nippon gene). Semen and tissue samples were cut into small pieces and combined with $250 \mu \mathrm{L}$ of STE buffer $(0.1 \mathrm{M} \mathrm{NaCl}$, $10 \mathrm{mM}$ Tris and $1 \mathrm{mM}$ EDTA $\mathrm{pH} 8.0$ ), $30 \mu \mathrm{L}$ of $10 \%$ sodium dodecylsulfate, and digested with proteinase $\mathrm{K}(20 \mu \mathrm{L}$ of $5 \mathrm{mg} / \mathrm{mL}$ ) at $55^{\circ} \mathrm{C}$ for 2 hours. For semen samples, DTT (dithiothreitol, final concentration, $0.6 \mathrm{mg} / \mathrm{mL}$ ) was added prior to proteinase $\mathrm{K}$ digestion. For both tissue and semen, digestion was continued for $2 \mathrm{hr}$ or until complete. After this step, a standard phenol-chloroform procedure for DNA extraction was performed.

Eight microsatellite loci were used in the PCR (D5S1470, D1S533, D12S67, D6S493, D5S820, D6S501, D19S582, and 
TABLE 1: Characterization of 8 microsatellite loci.

\begin{tabular}{lccccc}
\hline Locus & Allele & $\mathrm{N}$ & $\mathrm{H}$ (obs) & H (exp) & HW \\
\hline D5S1470 & 8 & 94 & 0.787 & 0.717 & NS \\
D1S533 & 6 & 105 & 0.733 & 0.73 & NS \\
D12S67 & 8 & 109 & 0.734 & 0.755 & NS \\
D6S493 & 7 & 108 & 0.731 & 0.687 & NS \\
D5S820 & 6 & 104 & 0.76 & 0.752 & NS \\
D6S501 & 6 & 101 & 0.743 & 0.752 & NS \\
D19S582 & 4 & 106 & 0.726 & 0.738 & NS \\
D10S611 & 7 & 103 & 0.738 & 0.698 & NS \\
\hline
\end{tabular}

$\mathrm{N}$ indicates the number of individuals typed; $\mathrm{H}$ (obs) and $\mathrm{H}(\exp )$ indicate the observed and expected heterozygosities. HW refers to deviation for Hardy-Weinberg equilibrium, and NS stands for nonsignificant.

D10S611). The calculated and observed heterozygosities of 8 microsatellite loci are shown in Table 1, and the probability of exclusion was 0.995 for the second parent (assuming that the first parent was correctly assigned). Each PCR product was purified by ethanol precipitation to remove nucleotides, primers, salts, and proteins. The $5^{\prime}$ ends of the forward primers were labeled with a fluorescent color, the amplification products were separated using capillary electrophoresis (ABI 310), and allele sizes were determined relative to an internal size standard. Polymerase chain reaction amplification for urine and fecal-derived DNA was repeated independently 3-7 times [29] whenever possible to check for genotyping errors such as allelic drop out.

Comparison of the infant and maternal genotypes allowed for the deduction of the paternal allele(s). Males whose alleles did not match the deduced paternal allele(s) were excluded as paternity candidates. When all candidate fathers except one were excluded, the remaining male was assumed to be the likely father. In cases in which all the candidate males were excluded, it was assumed that the father was probably an NTM whose DNA sample we failed to collect. Furthermore, the parentage likelihood was calculated using the program CERVUS 2.0 (Trisran Marshall, Edinburgh, UK; [30]). The allele frequencies of the entire population were used to compute the paternity exclusion probabilities, and the assigned fathers were required to have values of $90 \%$ or greater. For further details, see our previous reports $[20,21,28]$.

2.3. Statistical Analysis. We used binary logistic regression to test troop composition, and the number of NTMs affect the occurrence of troop takeover. The occurrence of takeover (yes/no) was the dependent variable, and the number of NTMs, troop males, and estrous females were independent variables. To detect multicollinearity between the independent variables, diagnostic statistics were examined via linear regression analysis. The variance inflation factors (VIF) determined were 1.818 (NTMs), 5.373 (troop males), and 4.638 (females). Values exceeding 10 are often considered to indicate multicollinearity. Based on our results, we concluded that there was no multicollinearity between the independent variables.
We also used binary logistic regression to test between the category of candidate fathers and the success of infant siring (yes/no). The infant siring (yes/no) was the dependent variable, and the category of candidate fathers (higher-ranking troop males, lower-ranking troop males and takeover males) and the number of infants born were independent variables.

\section{Results}

3.1. Features of Japanese Macaque Troop Takeover. All observed troop takeovers on Yakushima Island $(n=7)$ across 4 troops (1996-2003) occurred during the mating season (Table 2). Although multiple nontroop males (NTMs) appeared around the troop in the seasons when troop takeover occurred, no coalition of takeover males was observed. For example, successive troop takeovers by different NTMs occurred in troop B in 1996 and 2000. The two successive takeover males were never observed to cooperate in defeating the current alpha males and behaved aggressively toward each other. In both cases, the male who intruded later overcame the one who had intruded first.

When NTMs successfully took over a troop and assumed the alpha position, the 7 former alpha males never left the troop during the concurrent mating season. Although 2 of these previous alpha males suffered severe wounds during the mating season (usually the aggressor was unknown), they remained in the troop in the beta or gamma dominance position. During takeover mating seasons, there were few or no unweaned infants, and there was no directly observed infanticide. Circumstantial evidence for infanticide by NTMs was also lacking, as there were no infant disappearances during takeover mating seasons.

3.2. Determinants of Japanese Macaque Troop Takeover. Univariate binary logistic regression analyses revealed that the number of NTMs significantly predicted the occurrence of troop takeover but that the number of troop males and the number of estrous females did not (Table 3). To test for the independent effects of each variable, bivariate analyses were conducted, but, in these analyses, no significant results emerged. However, when controlling for the effects of the number of troop males and estrous females, the effect of the number of NTMs on takeover likelihood remained close to statistical significance. Also, after controlling for the number of estrous females, the effect of the number of troop males on takeover likelihood also approached statistical significance. For this Yakushima Island data set, the number of NTMs had the strongest effect on troop takeover, the number of troop males had a negligible effect, and the number of estrous females had no discernable effect on the likelihood of troop takeover.

All males that took over troops appeared when most of the troop females had not yet conceived (Table 4), and mating between nontroop takeover males and troop females was often observed, indicating that the males had reproductive opportunities.

Table 5 reveals that the tenure of takeover males in the alpha position was short, usually ranging from one season to 2 years, with one outlier tenure length of 4 years. One 
TABLE 2: The composition of the target troops.

(a) B troop

\begin{tabular}{llccc}
\hline Year & $\begin{array}{l}\text { Troop } \\
\text { takeover }\end{array}$ & $\begin{array}{c}\text { Num of } \\
\text { troop males }\end{array}$ & $\begin{array}{c}\text { Num of troop } \\
\text { females }\end{array}$ & $\begin{array}{c}\text { Num of } \\
\text { NTMs }\end{array}$ \\
\hline 1996 & Yes & 6 & $7(4)$ & 13 \\
1997 & No & 7 & $6(5)$ & 5 \\
1998 & No & 5 & $5(3)$ & 0 \\
1999 & Yes & 0 & $2(2)$ & 4 \\
2000 & Yes & 2 & $4(3)$ & 4 \\
2003 & No & $2(4)^{*}$ & $3(3)$ & 10 \\
\hline
\end{tabular}

* Two males who moved with females in the previous nonmating season were never found in B troop during the mating season; however, they were again found in the troop after the mating season was over.

(b) NA troop

\begin{tabular}{llccc}
\hline Year & $\begin{array}{l}\text { Troop } \\
\text { takeover }\end{array}$ & $\begin{array}{c}\text { Number of } \\
\text { troop males }\end{array}$ & $\begin{array}{c}\text { Number of } \\
\text { troop females }\end{array}$ & $\begin{array}{c}\text { Number of } \\
\text { NTMs }\end{array}$ \\
\hline 1997 & No & 15 & $15(11)$ & 0 \\
1998 & No & 12 & $13(6)$ & 0 \\
1999 & Yes & 7 & $6(6)$ & 11 \\
2000 & No & 7 & $7(4)$ & 2 \\
2003 & Yes & 1 & $5(4)$ & 13 \\
\hline
\end{tabular}

(c) Momoe troop

\begin{tabular}{clccc}
\hline Year & $\begin{array}{l}\text { Troop } \\
\text { takeover }\end{array}$ & $\begin{array}{c}\text { Number of } \\
\text { troop males }\end{array}$ & $\begin{array}{c}\text { Number of } \\
\text { troop females }\end{array}$ & $\begin{array}{c}\text { Number of } \\
\text { NTMs }\end{array}$ \\
\hline 2003 & Yes & 4 & $6(6)$ & 10 \\
\hline
\end{tabular}

(d) E troop

\begin{tabular}{llccc}
\hline Year & $\begin{array}{l}\text { Troop } \\
\text { takeover }\end{array}$ & $\begin{array}{c}\text { Number of } \\
\text { troop males }\end{array}$ & $\begin{array}{c}\text { Number of } \\
\text { troop females }\end{array}$ & $\begin{array}{c}\text { Number of } \\
\text { NTMs }\end{array}$ \\
\hline 2003 & Yes & 7 & $8(8)$ & 17 \\
\hline
\end{tabular}

TABLe 3: Contribution of the variables (B), standard error (SE), and significance $(\mathrm{P})$ of binary logistic regression model concerning the occurrence of troop takeover.

\begin{tabular}{|c|c|c|c|c|}
\hline \multicolumn{2}{|c|}{ Independent variable } & $\mathrm{B}$ & SE & $\mathrm{P}$ \\
\hline \multicolumn{5}{|c|}{ Univariate analyses } \\
\hline \multicolumn{2}{|c|}{ Number of NTMs } & 0.356 & 0.178 & $0.045^{*}$ \\
\hline \multicolumn{2}{|c|}{ Number of troop males } & -0.335 & 0.217 & 0.124 \\
\hline \multicolumn{2}{|c|}{ Number of estrus females } & -0.113 & 0.242 & 0.640 \\
\hline \multicolumn{5}{|c|}{ Bivariate analyses } \\
\hline \multirow{3}{*}{ NTM } & Controlling for: & & & \\
\hline & Troop males & 0.345 & 0.201 & 0.087 \\
\hline & Estrous females & 0.386 & 0.206 & 0.061 \\
\hline \multirow{2}{*}{ Troop males } & NTMs & -0.372 & 0.321 & 0.248 \\
\hline & Estrous females & -0.969 & 0.502 & 0.054 \\
\hline \multirow{2}{*}{ Estrous females } & NTMs & -0.330 & 0.553 & 0.537 \\
\hline & Troop males & 1.227 & 0.780 & 0.116 \\
\hline
\end{tabular}

${ }^{*} P<0.05$.

male was expelled, and 2 males were supplanted by other NTMs. Both the supplanted males remained in the troop as beta male for at least 1 more year. The remaining four males disappeared from the troop for unknown reasons (one might have died during the period of mass mortality).

3.3. Reproductive Success of Japanese Macaque Takeover Males. We compared the number of offspring sired by takeover males to that sired by high-ranking and low-ranking troop males (Table 6). Five offspring were not included in the analysis because we failed to collect sufficient samples to test their paternity. The number of high-ranking males was determined annually by the average number of receptive females in each troop: if the average number of estrous females was below 1.5, then only the alpha male was considered dominant, and if the average was 1.5 or above, then the number of high ranking males was increased to two (alpha and beta males). Six of nine infants were assumed to be sired by NTMs whose DNA samples we failed to collect, because all the candidate fathers (including 20 NTMs) were excluded by the analysis.

The result is that 3 of the $9(33.3 \%)$ takeover males succeeded in siring infants, while 4 of the 19 (21.1\%) highranking troop males and 8 of $56(16.0 \%)$ low-ranking troop males did so. Step-wise logistic regression analyses revealed that the factor "Category of candidate fathers" and the factor "Number of infants" are the significant factors predicted sirehood (Table 7). The factor "Category of candidate father (1)" divides takeover males from other males, and "Category of candidate father (2)" divides high-ranking males from other males. The analysis showed that only "Category of candidate father (1)" is significant, so takeover males can expect higher reproductive success than males in other categories.

\section{Discussion}

4.1. Features of Japanese Macaque Troop Takeover. Troop takeover only occurred in the mating season, consistent with the idea that such actions are part of a reproductive strategy. Once appearing in the troop, NTMs rapidly established high rank (Table 4). Although takeover males were sometimes attacked by coalitions of troop males, such attacks never succeeded in expelling the intruder from the troop.

A newly dominant male could benefit from committing infanticide when he has not possibly sired the infant and very likely to sire the next. However, the only observed infanticide in this population involved a troop male who recently rose in rank, not a male who took over the troop [21], and there was no direct observation of infanticide, attempted infanticide, or indirect evidence of infanticide by takeover males. There are several reasons why takeover males may not use infanticide as a reproductive tactic. First, NTMs entering a troop encountered few unweaned infants (Table 2), so the opportunities may have been few. Second, takeover males have immediate competing interests, namely, following and consorting with estrous females. Females show prolonged estrous [31] and often try to mate with multiple males, so dominant males spend a great deal of time mate guarding. Third, resident males may prevent infanticide. In Japanese macaques, infanticide, though rarely observed, is most likely to occur when there are no resident males to defend the infant against attacks [10]. 
TABLE 4: Factors associated with troop takeover.

\begin{tabular}{|c|c|c|c|c|c|c|c|c|c|}
\hline Troop & Year & Male & $\begin{array}{l}\text { Date he was first } \\
\text { consorting with a } \\
\text { troop female }\end{array}$ & $\begin{array}{l}\text { Date the alpha } \\
\text { male first showed } \\
\text { submissive } \\
\text { behavior }\end{array}$ & $\begin{array}{l}\text { Fate of the } \\
\text { alpha male }\end{array}$ & $\begin{array}{c}\text { Number of } \\
\text { estrous } \\
\text { females }\end{array}$ & $\begin{array}{l}\text { Infants } \\
\text { born }\end{array}$ & $\begin{array}{c}\text { Infants } \\
\text { conceived } \\
\text { after his } \\
\text { appearance }\end{array}$ & $\begin{array}{c}\text { Number of } \\
\text { unweaned } \\
\text { infants }\end{array}$ \\
\hline B & 1996 & $\begin{array}{c}\mathrm{PE} \\
\mathrm{MR}\end{array}$ & $\begin{array}{l}\text { 17th October } \\
5 \text { th November }\end{array}$ & $\begin{array}{l}\text { 24th October } \\
\text { 9th November }\end{array}$ & Stayed & 4 & 1 & $\begin{array}{l}1 \\
1\end{array}$ & 2 \\
\hline NA & 1999 & BT & No data & No data & Stayed & 6 & 3 & 1 & 0 \\
\hline B & 1999 & MS & No data & No data & $*$ & 2 & 1 & 1 & 0 \\
\hline B & 2000 & $\begin{array}{l}\mathrm{AO} \\
\mathrm{MA}\end{array}$ & $\begin{array}{l}\text { No data } \\
\text { No data }\end{array}$ & $\begin{array}{l}\text { No data } \\
\text { No data }\end{array}$ & Stayed & 3 & 1 & $\begin{array}{l}1 \\
1\end{array}$ & 0 \\
\hline NA & 2003 & $\mathrm{MD}$ & 26th October & 4th November & Stayed & 5 & 3 & 2 & 1 \\
\hline Momoe & 2003 & $\mathrm{TR}$ & 25th October & 5th November & Stayed & 5 & 2 & 1 & 0 \\
\hline E & 2003 & $\mathrm{MN}$ & 14th October & 15th October & Stayed & 8 & 6 & 5 & 0 \\
\hline
\end{tabular}

*All resident males had left the troop before MS appeared in the troop.

TABLE 5: Tenure of takeover males in the alpha position.

\begin{tabular}{|c|c|c|c|c|c|c|}
\hline Troop & Male & Time of appearance & Time of his leaving & $\begin{array}{c}\text { Reason he lost his } \\
\text { tenure }\end{array}$ & $\begin{array}{c}\text { Tenure as } \\
\text { top-dominant male }\end{array}$ & $\begin{array}{c}\text { Number of siring } \\
\text { infant }\end{array}$ \\
\hline B & $\mathrm{PE}$ & 1996 October & 1996 November & Another takeover & Part of one season & 0 \\
\hline B & MR & 1996 October & 1998 August & Presumably died & 2 years & 0 \\
\hline NA & $\mathrm{BT}$ & 1999 October & 1999 November & He left voluntarily & Part of one season & 0 \\
\hline B & MS & 1999 October & 2001 & Another takeover & 1 year* & 0 \\
\hline B & $\mathrm{AO}$ & 2000 October & 2002 & Another takeover & Part of one season* & 0 \\
\hline B & MA & 2000 October & 2002 & Another takeover & 2 years & 1 \\
\hline NA & $\mathrm{MD}$ & 2003 November & 2004 & ? & 1 year & 1 \\
\hline Momoe & TR & 2003 November & 2004 or 2005 & ? & 1 year or 2 years & 0 \\
\hline E & $\mathrm{MN}$ & 2003 October & $\begin{array}{l}\text { Still in the troop in } \\
2009\end{array}$ & Another takeover & 4 years & 2 \\
\hline
\end{tabular}

TABLE 6: Reproductive success of takeover males.

\begin{tabular}{|c|c|c|c|c|c|c|c|c|}
\hline \multirow[t]{2}{*}{ Year } & \multirow[t]{2}{*}{ Troop } & \multirow[t]{2}{*}{ Troop takeover } & \multirow{2}{*}{$\begin{array}{l}\text { Average number of } \\
\text { estrous females per } \\
\text { day }\end{array}$} & \multirow{2}{*}{$\begin{array}{c}\text { Infants born (paternity } \\
\text { decided) }\end{array}$} & \multicolumn{4}{|c|}{ Number of male siring offspring } \\
\hline & & & & & $\begin{array}{l}\text { High-ranking } \\
\text { troop male }^{\mathrm{c}}\end{array}$ & $\begin{array}{l}\text { Low-ranking } \\
\text { troop male }^{\mathrm{c}}\end{array}$ & NTM & Takeover \\
\hline $1996^{a}$ & B & Yes & 1.53 & $1(1)$ & $0(2)$ & $0(4)$ & 1 & $0(2)$ \\
\hline $1997^{a}$ & B & No & 1.73 & $3(2)$ & $1(2)$ & $0(5)$ & 1 & - \\
\hline $1998^{a}$ & B & No & No data & 0 & $0(1)$ & $0(4)$ & 0 & - \\
\hline $1999^{a}$ & B & Yes & No data & $1(1)$ & - & - & 1 & $0(1)$ \\
\hline $2000^{\mathrm{a}}$ & B & Yes & No data & $1(1)$ & $0(1)$ & $0(1)$ & 0 & $1(2)$ \\
\hline 2003 & B & No & 0.52 & 0 & $0(1)$ & $0(1)$ & 0 & - \\
\hline $1997^{\mathrm{b}}$ & NA & No & 2.42 & $11(9)$ & $2^{\mathrm{d}}(2)$ & $3(13)$ & 3 & - \\
\hline $1998^{\mathrm{b}}$ & NA & No & & 0 & $0(2)$ & $0(10)$ & 0 & - \\
\hline $1999^{a}$ & NA & Yes & 1.77 & $3(2)$ & $0(2)$ & $1(5)$ & 1 & $0(1)$ \\
\hline $2000^{\mathrm{a}}$ & NA & No & 1.28 & $1(1)$ & $0(2)$ & $1(5)$ & 0 & - \\
\hline 2003 & NA & Yes & 1.63 & $3(2)$ & $1(1)$ & $0(0)$ & 0 & $1(1)$ \\
\hline 2003 & $\mathrm{E}$ & Yes & 2.13 & $6(5)$ & $0(2)$ & $1(5)$ & 2 & $1^{\mathrm{e}}(1)$ \\
\hline 2003 & Momoe & Yes & 1.39 & $2(2)$ & $0(1)$ & $2(3)$ & 0 & $0(1)$ \\
\hline Total & & & & $32(26)$ & $4(19)$ & $9(56)$ & 9 & $3(9)$ \\
\hline
\end{tabular}


TABLE 7: Contribution of the variables (B), standard error (SE), and significance $(\mathrm{P})$ of binary logistic regression model concerning the success of infant siring.

\begin{tabular}{lccc}
\hline Independent variables & $\mathrm{B}$ & SE & $\mathrm{P}$ \\
\hline Category of candidate father & & & .061 \\
Category of candidate father & & & \\
$(1)$ & 1.834 & .906 & $.043^{*}$ \\
$(2)$ & 0.882 & .760 & .246 \\
Number of infants born & .223 & .078 & $.004^{*}$ \\
\hline
\end{tabular}

$P<0.05$. The factor "Category of candidate father (1)" divides takeover males from other males, and "Category of candidate father (2)" divides highranking males from other males. The analysis showed that only "Category of candidate father (1)" is significant.

4.2. Determinants of Japanese Macaque Troop Takeover. The number of NTMs associating with a troop was the main predictor of troop takeover. This was the case despite the fact that NTMs did not cooperate with each other during takeovers. The number of NTMs may positively influence the probability of takeover because (1) the higher the number of males in the NTM group, the greater the probability that one of them will outrank the alpha male, (2) NTMs may be drawn to groups with relatively weak alpha males, or (3) large groups of NTMs who independently attack the troop may wear down resident males from their repeated efforts, even though only one of them takes over the troop at a time.

Another possibility is that the occurrence of troop takeover itself leads to the increased number of NTMs, because the number of NTMs includes those who visited after the occurrence of troop takeover. When the troop is taken over, it become less cohesive because (1) the takeover male often copulates on the periphery of the troop, perhaps to prevent cooperative aggression by troop males [6], and (2) takeover males cannot make affiliative relationship with nonestrous females or other troop males, and this results in troop members moving in separate groups $[5,24]$. This lack of cohesiveness may attract NTMs who can easily approach estrous females and may sometimes lead to a second troop takeover.

Our analysis failed to show that the number of troop males affects the occurrence of troop takeover. However, previous studies indicate that the number of troop males negatively correlates with the number of NTMs on a daily basis [6], and troop takeover tends to occur in the troops with small numbers of troop males [17]. Furthermore, in the main island of Japan where troop size is much bigger than Yakushima, troop takeover is rarely observed. So, these results should not be construed as evidence that the number of troop males generally has no effect on takeover. First, the association was in the expected direction (the few males in the troop the more likely a takeover), and when controlling for the number of estrous females, the relationship approached significance (Table 3 ). Second, since troop size on Yakushima Island is generally small, there may not have been enough variation in the number of troop males across groups and years to observe a discernable effect of troop male number on troop takeover (floor effect). Third, the effect of the number of troop males on troop defensibility may have been diminished if some resident males sought mating opportunity on the periphery [6] or if some resident males were not physically mature enough to compete with challenger males.

\subsection{Reproductive Success of Japanese Macaque Takeover Males.} The result showed that 3 of the $9(33.3 \%)$ takeover males succeeded in siring infants. The logistic regression analyses revealed that takeover males can expect higher reproductive success than males of other categories. But the success rate is smaller compared to that of other species $[2,3,8]$. Why did these males not have higher reproductive success? First, as the logistic regression model indicated, a male's success of siring an infant depends on the number of infants born. Troops with fewer males would be easier to takeover because a small number of males implies less defensibility by troop males $[5,17]$. However, at the same time, it also indicates that the number of estrous females in the troop is small because the sex ratio of this population is nearly uniform. Thus, it is assumed that the males could not sire many infants due to the small size of the troops.

Second, takeover males often mate with estrous females in the periphery of the troop [6], probably thereby avoiding the troop males' aggression. However, taking a female to the periphery of the troop also increases the chances that those females will meet other novel NTMs and also causes decreased cohesiveness of the target troop. Estrous females sometimes leave the troop temporarily and meet with NTMs or low-ranking males in locations where they cannot be detected by other males. These promiscuous behaviors of females are considered as a counterstrategy against infanticide and cause difficulties for males to monopolize estrous females.

If a male retains his dominant status for a long period, he could increase the possibility of enjoying high reproductive success, but this was not the case. The main reason that a usurping male loses the top dominance so quickly is another troop takeover (Table 5). Considering the cost of the time and energy to take over the troop, it seems strange that usurping males lose their tenure so quickly. However, in this population, maintaining high rank does not guarantee high reproductive success. Given the presence of a challenger trying to enter his troop, the alpha male must choose whether to take the risk of receiving severe wounds or to turn over his alpha position. The takeover strategy appears to be a short-term, high-risk strategy for prime males to gain immediate chances of siring a few offspring which may provide more reproductive opportunities than entering gradually and peacefully at the bottom of the hierarchy, remaining as a NTM, or rejoining his previous troop.

4.4. Comparison to Takeovers in Other Multimale Groups. Troop takeover has been observed in several multimale primate groups $[2,3,8,17]$. With the exception of the Japanese macaque, alpha status confers clear reproductive benefits in the above species, which drives males to challenge troop takeover. This study and previous research into the relationship between male dominance rank and reproductive success 
in Japanese macaques have yielded mixed results $[20,28]$. This may be one reason that troop takeover is relatively rare and opportunistic in this species.

Another remarkable feature of Japanese macaque takeovers is that NTMs do not cooperate. In white-faced capuchins, on the other hand, 4 of 7 (57\%) takeovers involved multimale, cooperative invasions. In most of these cases, invaders matched or outnumbered resident males. Larger numbers of cooperating intruders should increase the likelihood of troop takeover, but it also increases within group competition after takeover. Further investigation will be needed to account for the variability in takeover strategies within and across primate species.

\section{Acknowledgment}

The author thanks Drs. Yukimaru Sugiyama, Jyuichi Yamagiwa, Shigeo Uehara, Osamu Takenaka, Michael A. Huffman, and colleagues at the Ecology and Behavior Department for their continuous support of his work and critical comments. Also, he thanks Dr. Shin Nakamura for special technical Support for DNA analysis. Also, he thanks all members of the Yakushima Research Group for their discussions on Yakushima Island and thanks Dr. Elizabeth Nakajima and Dr. Fred B. Bercovitch for correcting his paper. This research was supported by the Research Fellowships of the Japan Society for the Promotion of Science for Young Scientists (No. 9611) and a Grant for Global COE (A6) to Kyoto University from the Ministry of Education, Culture, Sports, Science and Technology of Japan. This study complied with the protocols approved by the Animal Care and Use Guideline of Primate Research Institute, Kyoto University.

\section{References}

[1] A. Pusey and C. Packer, "Dispersal and philopatry," in Primate Societies, B. C. Smuts, D. L. Seyfarth, R. M. Wrangham, and T. T. Struhsaker, Eds., pp. 250-266, Chicago Uniersity Press, Chicago, Ill, USA, 1987.

[2] K. M. Jack and L. Fedigan, "Male dispersal patterns in whitefaced capuchins, Cebus capucinus part 2: patterns and causes of secondary dispersal," Animal Behaviour, vol. 67, no. 4, pp. 771-782, 2004.

[3] M. A. Van Noordwijk and C. P. Van Schaik, "Career moves: transfer and rank challenge decisions by male long-tailed macaques," Behaviour, vol. 138, no. 3, pp. 359-395, 2001.

[4] A. Paul and J. Kuester, "Intergroup transfer and incest avoidance in semifree-ranging Barbary Macaques (Macaca-Sylvanus) at Salem (Frg)," American Journal of Primatology, vol. 8, no. 4, pp. 317-322, 1985.

[5] J. Yamagiwa, "Socio-sexual factors of troop fission in wild Japanese monkeys (Macaca fuscata yakui) on Yakushima Island, Japan," Primates, vol. 26, no. 2, pp. 105-120, 1985.

[6] S. Hayakawa, "Female defensibility in a small troops of Japanese macaques vis-à-vis nontroop males and copulation on the periphery of the troop," International Journal of Primatology, vol. 28, no. 1, pp. 73-96, 2007.

[7] C. Borries, "Male dispersal and mating influxes in Hanuman langurs living in multi-male groups," in Primate Males, P. Kappeler, Ed., pp. 146-158, Cambredge University Press, Cambridge, Mass, USA, 2000.
[8] C. Borries, "Infanticide in seasonally breeding multimale groups of Hanuman langurs (Presbytis entellus) in Ramnagar (South Nepal)," Behavioral Ecology and Sociobiology, vol. 41, no. 3, pp. 139-150, 1997.

[9] J. R. de Ruiter, J. A. R. A. M. van Hooff, and W. Scheffrahn, "Social and genetic aspects of paternity in wild long-tailed macaques (Macaca fascicularis)," Behaviour, vol. 129, no. 3-4, pp. 203-224, 1994.

[10] K. Yamada and M. Nakamichi, "A fatal attack on an unweaned infant by a non-resident male in a free-ranging group of Japanese macaques (Macaca fuscata) at Katsuyama," Primates, vol. 47, no. 2, pp. 165-169, 2006.

[11] C. Borries, K. Launhardt, C. Epplen, J. T. Epplen, and P. Winkler, "Males as infant protectors in Hanuman langurs (Presbytis entellus) living in multimale groups-Defence pattern, paternity and sexual behaviour," Behavioral Ecology and Sociobiology, vol. 46, no. 5, pp. 350-356, 1999.

[12] Y. Sugiyama, "Life history of male Japanese monkeys," in Advance in the study of behavior, J. Rosenblat and R. Hinde, Eds., pp. 255-284, Academic Press, New York, NY, USA, 1976.

[13] D. S. Sprague, "Life history and male intertroop mobility among Japanese macaques (Macaca fuscata)," International Journal of Primatology, vol. 13, no. 4, pp. 437-454, 1992.

[14] D. S. Sprague, "Age, dominance rank, natal status, and tenure among male macaques," American Journal of Physical Anthropology, vol. 105, no. 4, pp. 511-521, 1998.

[15] D. Sprague, S. Suzuki, and T. Tsukahara, "Variation in social mechanisms by which males attained the alpha rank among Japanese macaques," in Evolution and Ecology of Macaque Societies, J. E. Fa and D. Lindburg, Eds., pp. 444-458, Cambridge University Press, New York, NY, USA, 1996.

[16] J. Yamagiwa and D. A. Hill, "Intraspecific variation in the social organization of Japanese macaques: past and present scope of field studies in natural habitats," Primates, vol. 39, no. 3, pp. 257-273, 1998.

[17] S. Suzuki, D. A. Hill, and D. S. Sprague, "Intertroop transfer and dominance rank structure of nonnatal male Japanese macaques in Yakushima, Japan," International Journal of Primatology, vol. 19, no. 4, pp. 703-722, 1998.

[18] T. Maruhashi, "Activity patterns of a troop of Japanese monkeys (Macaca fuscata yakui) on Yakushima Island, Japan," Primates, vol. 22, no. 1, pp. 1-14, 1981.

[19] N. Okayasu, "Contrast of estrus in accordance with social contexts between two troops of wild Japanese macaques on Yakushima," Anthropological Science, vol. 109, no. 2, pp. 121139, 2001.

[20] S. Hayakawa, "Male-female mating tactics and paternity of wild Japanese macaques (Macaca fuscata yakui)," American Journal of Primatology, vol. 70, no. 10, pp. 986-989, 2008.

[21] J. Soltis, R. Thomsen, K. Matsubayashi, and O. Takenaka, "Infanticide by resident males and female counter-strategies in wild Japanese macaques (Macaca fuscata)," Behavioral Ecology and Sociobiology, vol. 48, no. 3, pp. 195-202, 2000.

[22] M. Matsubara and D. S. Sprague, "Mating tactics in response to costs incurred by mating with multiple males in wild female Japanese macaques," International Journal of Primatology, vol. 25, no. 4, pp. 901-917, 2004.

[23] R. Thomsen and J. Soltis, "Socioecological context of parturition in wild Japanese macaques (Macaca fuscata) on Yakushima Island," International Journal of Primatology, vol. 21, no. 4, pp. 685-696, 2000.

[24] S. Horiuchi, "Affiliative relations among male Japanese macaques (Macaca fuscata yakui) within and outside a troop on Yakushima Island," Primates, vol. 46, no. 3, pp. 191-197, 2005. 
[25] T. Maruhashi, "Feeding behavior and diet of the Japanese monkey (Macaca fuscata yakui) on Yakushima Island, Japan," Primates, vol. 21, no. 2, pp. 141-160, 1980.

[26] T. Maruhashi, "An ecological study of troop fissions of Japanese monkeys (Macaca fuscata yakui) on Yakushima Island, Japan," Primates, vol. 23, no. 3, pp. 317-337, 1982.

[27] D. S. Sprague, "Mating by nontroop males among the Japanese macaques of Yakushima Island," Folia Primatologica, vol. 57, no. 3, pp. 156-158, 1991.

[28] J. Soltis, R. Thomsen, and O. Takenaka, "The interaction of male and female reproductive strategies and paternity in wild Japanese macaques, Macaca fuscata," Animal Behaviour, vol. 62, no. 3, pp. 485-494, 2001.

[29] P. Taberlet, S. Griffin, B. Goossens et al., "Reliable genotyping of samples with very low DNA quantities using PCR," Nucleic Acids Research, vol. 24, no. 16, pp. 3189-3194, 1996.

[30] T. C. Marshall, J. Slate, L. E. B. Kruuk, and J. M. Pemberton, "Statistical confidence for likelihood-based paternity inference in natural populations," Molecular Ecology, vol. 7, no. 5, pp. 639-655, 1998.

[31] N. Okayasu, "Prolonged estrus in female Japanese macaques (Macaca fuscata yakui) and the social influence on estrus: with special reference to male intertroop movement," in Topics in Primatology Vol 2 : Behavior, Ecology, and Conservation, $\mathrm{N}$. Itoigawa, Y. Sugiyama, and G. P. Sackett, Eds., pp. 163-178, University of Tokyo Press, Tokyo, Japan, 1992. 

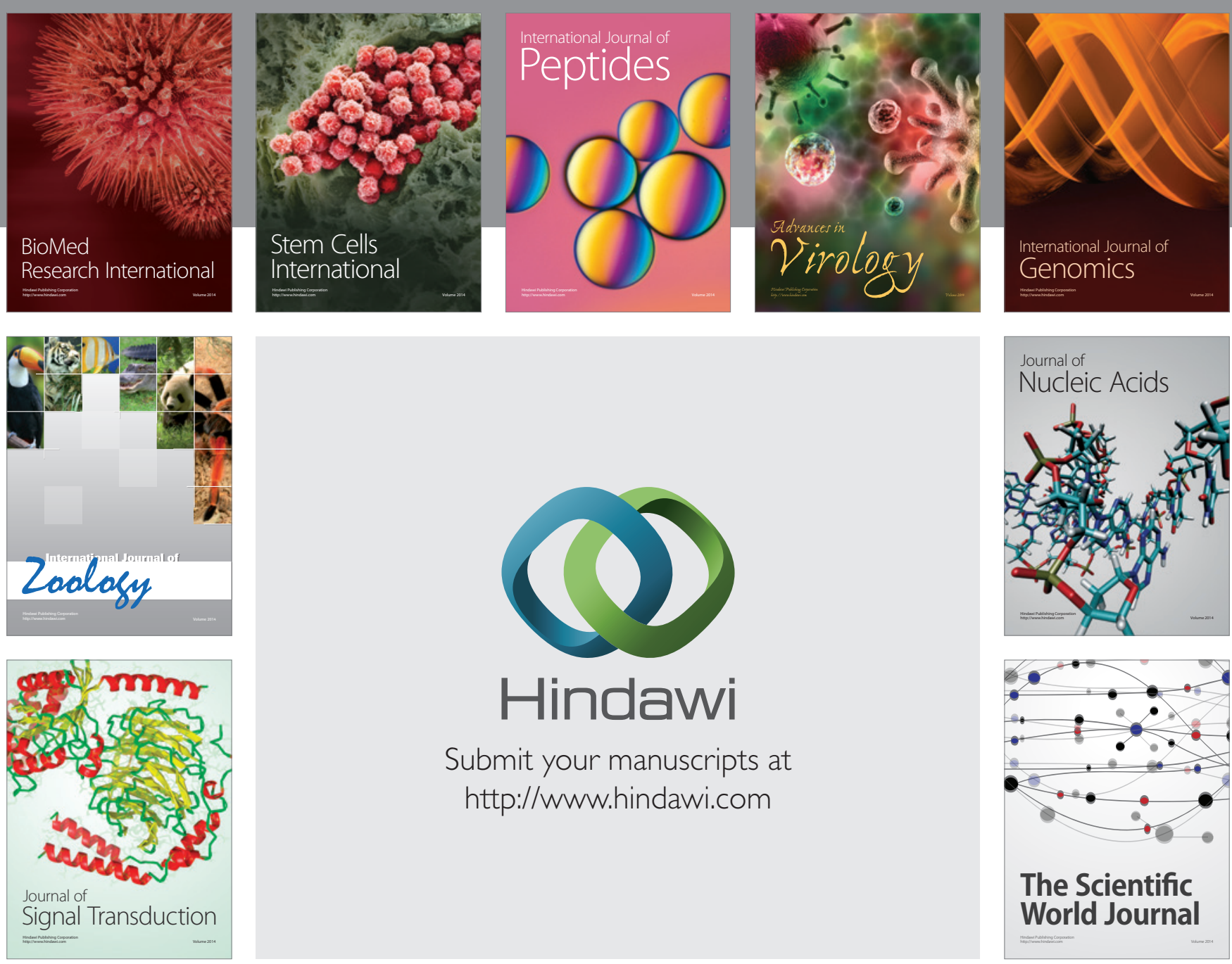

Submit your manuscripts at

http://www.hindawi.com
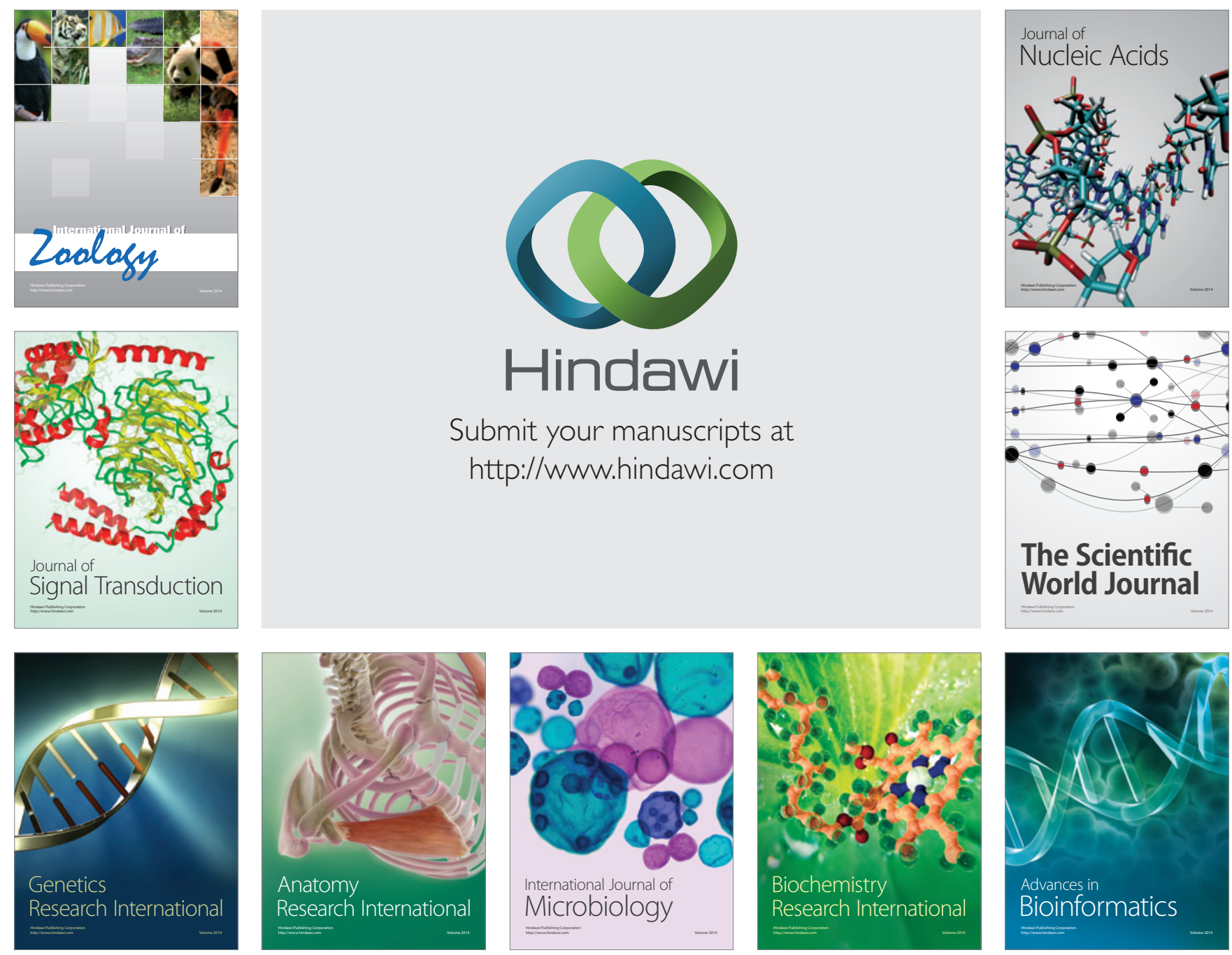

The Scientific World Journal
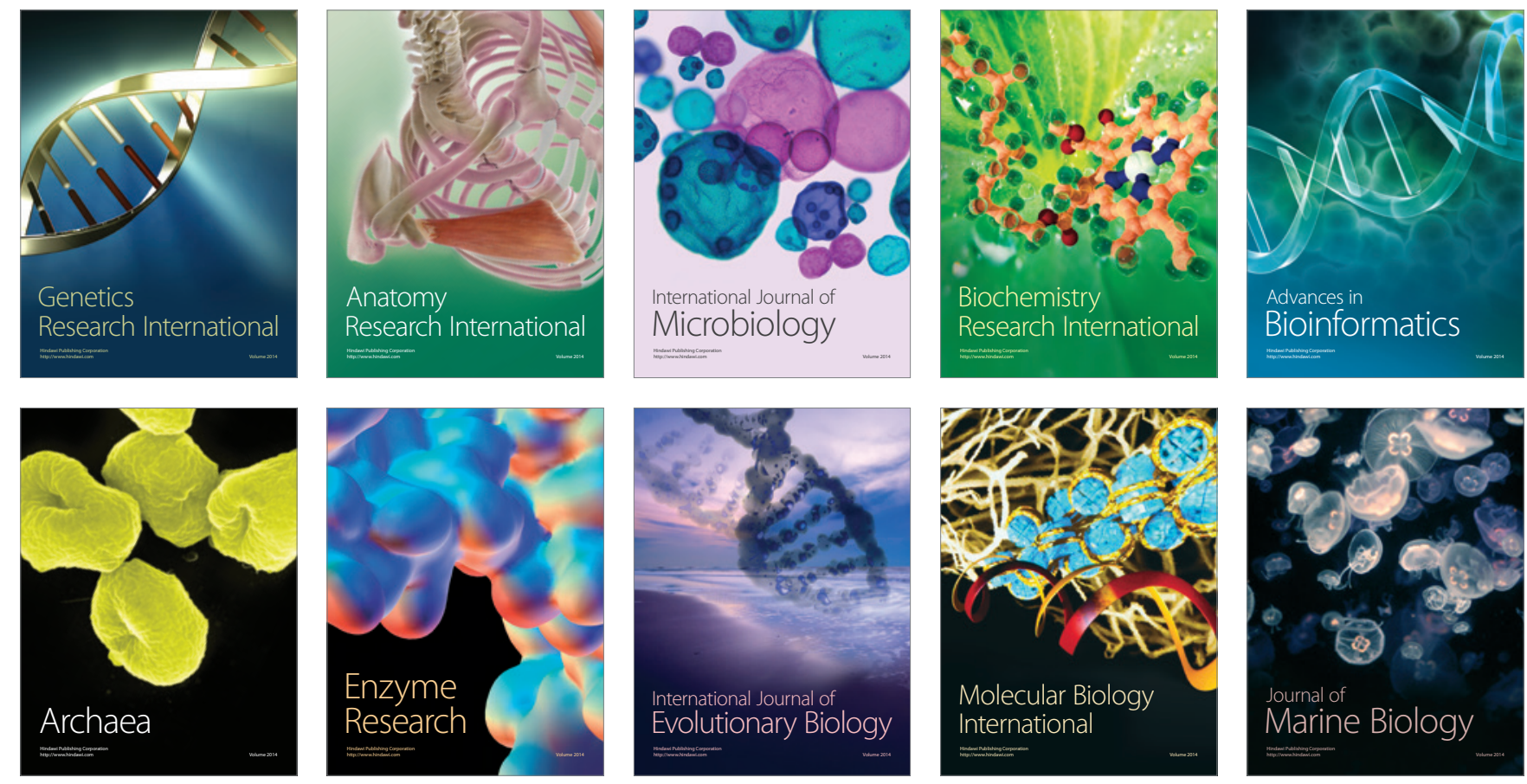